\title{
Effects of Procaine on the Ventricular Muscle of Bullfrog
}

\author{
Junna HATAE \\ Department of Physiology, Faculty of Medicine, Fukuoka University \\ Nishi-ku, Fukuoka, 814 Japan
}

\begin{abstract}
The effects of procaine on the contractility of the bullfrog's ventricular muscle were investigated. The addition of $10^{-5} \mathrm{~g} / \mathrm{ml}$ of procaine potentiated the twitch tension which was accompanied by an elevation as well as a prolongation of the action potential plateau. This positive inotropism of procaine was not induced by endogenous catecholamine because a $\beta$-blocking agent did not influence this twitch potentiation. The twitch potentiation was increased in proportion to the external $\mathrm{Ca}$ concentration, suggesting the possibility of augmentation of $\mathrm{Ca}$ influx during the action potential. In normal Ringer solution, procaine suppressed potassium contracture which was composed of two components: an initial phasic component and a late tonic one. Potassium contracture after perfusion with $\mathrm{Ca}$-free solution was also suppressed by procaine. However, potassium contracture which had been treated previously with La was composed of only a tonic component and was potentiated by procaine in spite of perfusion with Ca-free solution. The tonic component of potassium contracture may be considered to occur with intracellular $\mathrm{Ca}$. Procaine may increase the $\mathrm{Ca}$ inward current, acting on the intracellular $\mathrm{Ca}$ storage site and consequently accelerate the excitation-contraction coupling in frog ventricular muscle.
\end{abstract}

Procaine, like other local anesthetics, is known to act as a stabilizer in nerve or muscle membranes. It has been shown that procaine inhibited both the peak sodium and the steady state potassium conductance in squid giant axon (NARAHASHI et al., 1967) and in lobster giant axon (Blaustein and Goldman, 1966). As to the skeletal muscle, procaine reduced the outward current produced by depolarization in snake twitch muscle (HeISTRACHER and HuNT, 1969) and in barnacle muscle (Hagiwara et al., 1969). This drug also diminished potassium conductance in the guinea pig's urinary bladder (KURIHARA, 1975; KURIHARA and SAKAI, 1976). Weidmann (1955) reported in mammalian Purkinje fibers that local anethetics such as cocaine or procaine amide reduced the rate of rise and the magnitude of the action potential, concluding that local anesthetics procaine inhibited the rapid $\mathrm{Na}$ inward current.

Received for publication August 11, 1978 波多江純真 
The effects of procaine on the mechanical properties have been studied in the skeletal, heart and smooth muscles. In skeletal muscle, there are two findings. One is that procaine suppressed caffeine contractures in frog (FEINSTEIN, 1963; GRUENER, 1967) and inhibited Ca release from the sarcoplasmic reticulum in rabbit (CARvalho, 1968) and in frog (Weber and Herz, 1968). In heart muscle, negative inotropic effects of procaine were observed in turtle (BAIRD and HARDMAN, 1961) and sheep heart (THORENS, 1971). On the contrary, in rat skeletal muscle IsAACSON et al., (1970) reported that procaine increased the force of contraction and BONDANI and KARLER (1970) reported an inhibition of $\mathrm{Ca}$ binding to microsomes.

The present study is concerned with the effects of procaine on the contractile responses in the bullfrog's ventricular muscle.

\section{METHODS}

Small strips obtained from the bullfrog (Rana catesbeiana) ventricle were used throughout the experiment. Two sorts of chamber were used in this experiment; a sucrose-gap chamber which was the same as previously described (KAWATA and HATAE, 1977) and an organ bath chamber $(2.5 \mathrm{ml})$. In the organ bath chamber, one end of the muscle was fixed with silk threads to an acryl rod and the other end to a force-displacement transducer (Nihon-Kohden, SB-1TH). Isometric tensions of these muscles were recorded on a Nihon-Kohden recticorder (RJG-3024). All muscle preparations were driven with short $(10 \mathrm{msec})$ square current pulses of a constant frequency of 12 shocks/min. To investigate the intracellular action potential, a microelectrode technique was used in a single sucrose-gap chamber.

The control Ringer solution had the following composition (in $\mathrm{mm}$ ): $\mathrm{NaCl}$ 111, $\mathrm{KCl} 2.7, \mathrm{CaCl}_{2} 2.4, \mathrm{NaHCO}_{3} 2.4, \mathrm{KH}_{2} \mathrm{PO}_{4}$ 0.37, glucose 11.1; the $\mathrm{pH}$ of the solution was 7.2.

For the potassium contracture experiment, a low $\mathrm{Na}$ (14 mm)-high $\mathrm{K}$ (100 mm) solution was used. A Ca-free solution was prepared by simply omitting $\mathrm{CaCl}_{2}$. In the case of the experiment with $\mathrm{LaCl}_{3}$, La precipitates out in solutions containing buffer ions such as $\mathrm{HCO}_{3}{ }^{-}$or $\mathrm{H}_{2} \mathrm{PO}_{4}{ }^{-}$, so $\mathrm{NaHCO}_{3}$ and $\mathrm{KH}_{2} \mathrm{PO}_{4}$ of normal Ringer solution was replaced by Tris $\mathrm{Cl}$ before application of $\mathrm{La}$. The concentration of La was $200 \mu \mathrm{M}$.

Except in the dose-response experiment, $10^{-5} \mathrm{~g} / \mathrm{ml}$ procaine hydrochloride solution was used. In the dose-response experiment, the range of concentrations of procaine was between $1 \times 10^{-7}$ and $1 \times 10^{-4} \mathrm{~g} / \mathrm{ml}$.

\section{RESULTS}

1. Dose dependency of procaine-induced potentiation of the twitch tension

Procaine produced a dose-dependent twitch potentiation at concentrations between $10^{-7}$ and $10^{-4} \mathrm{~g} / \mathrm{ml}$ in the bullfrog's ventricular muscle (Fig. 1). Figure 1a 


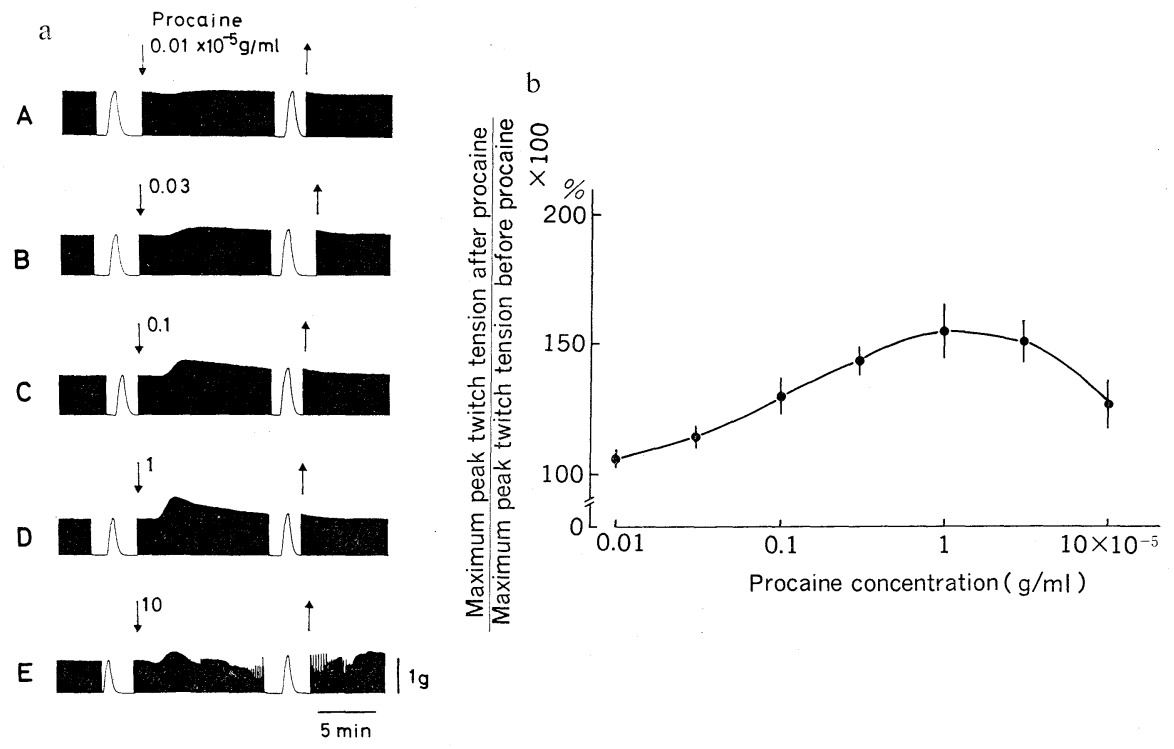

Fig. 1. Dose-response relations for the procaine-induced potentiation of twitch contraction. a: An example of experiments. Procaine-containing Ringer was perfused between the two arrows for about $12 \mathrm{~min}$. In all records, the last control contraction and the last procaine-treated contraction were recorded at a faster paper speed $(\mathrm{mm} / \mathrm{sec})$ than the rest of the experiment $(\mathrm{mm} / \mathrm{min})$. b: Dose-response curve of procaine-induced potentiation. Each point represents the mean \pm S.E. of seven frogs.

shows a typical result. Procaine perfused between the downward and upward arrows for $12 \mathrm{~min}$ and the concentrations of procaine were $10^{-7} \mathrm{~g} / \mathrm{ml}$ in $\mathrm{A}, 3 \times$ $10^{-7} \mathrm{~g} / \mathrm{ml}$ in $\mathrm{B}, 10^{-6} \mathrm{~g} / \mathrm{ml}$ in $\mathrm{C}, 10^{-5} \mathrm{~g} / \mathrm{ml}$ in $\mathrm{D}$ and $10^{-4} \mathrm{~g} / \mathrm{ml}$ in $\mathrm{E}$. The smallest effective concentration of procaine necessary to potentiate the twitch tension was $10^{-7} \mathrm{~g} / \mathrm{ml}$. The maximum response of procaine on the twitch potentiation was obtained at a concentration of $10^{-5} \mathrm{~g} / \mathrm{ml}$. Above the concentration of $10^{-4} \mathrm{~g} / \mathrm{ml}$, there sometimes was a block of twitch tension, probably because of the increase in the threshold of action potential elicitation. Figure $1 \mathrm{~b}$ graphically expresses the results from seven frogs. The ordinate shows the peak tension relative to that of the control. The vertical bars represent the standard errors of the means. The maximum twitch increased to $154.9 \pm 10.8 \%$ at a concentration of $10^{-5} \mathrm{~g} / \mathrm{ml}$.

\section{The effects of procaine on the electrical and mechanical properties}

The intracellular action potential of a ventricular muscle was measured simultaneously with its tension. Figure 2 shows the effect of procaine $\left(10^{-5} \mathrm{~g} / \mathrm{ml}\right)$ both on the electrical and mechanical responses. Figure $2 \mathrm{~A}$ shows the control response. Figure $2 \mathrm{~B}$ shows a typical twitch augmentation under procaine. 


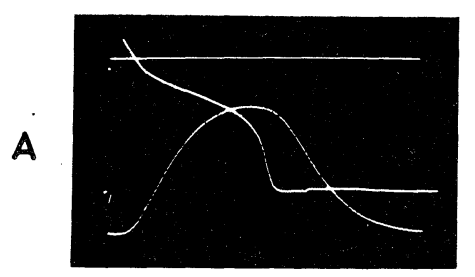

Fig. 2. Record A: Action potential and twitch tension in normal Ringer solution. B: The effect of procaine $\left(10^{-5} \mathrm{~g} / \mathrm{ml}\right)$ on action potential and twitch tension.

The resting potential was not changed by the application of procaine. The plateau phase of the action potential was elevated and the duration of the action potential was prolonged by procaine.

The peak tension and the maximal rate of tension development were increased by procaine.

\section{Influence of a $\beta$-blocking agent}

In order to examine whether this positive inotropic effect produced by procaine was due to the release of endogenous catecholamine or not, a $\beta$-blocking agent, propranolol, was used. Figure $3 \mathrm{~A}$ shows the effect of procaine on twitch tension in normal Ringer solution. The downward arrow indicates the onset of application of $10^{-5} \mathrm{~g} / \mathrm{ml}$ procaine and the upward arrow the beginning of washout. Figure 3B, C and $\mathrm{D}$ show the records obtained in the pretreatment with propranolol of the concentration $1 \times 10^{-7} \mathrm{M}$ in $\mathrm{B}, 1 \times 10^{-6} \mathrm{M}$ in $\mathrm{C}$ and $1 \times 10^{-5} \mathrm{M}$ in D, respectively. Thereafter $10^{-5} \mathrm{~g} / \mathrm{ml}$ procaine containing a respective concentration of propranolol was applied for $5 \mathrm{~min}$. The muscle was then washed with the control Ringer solution until the twitch tension was restored and reached a steady state level; $10^{-5} \mathrm{~g} / \mathrm{ml}$ procaine was applied again (Fig. 1E).

Since the positive inotropic effect produced by procaine was not suppressed by propranolol, it can be concluded that the endogenous catecholamine release does not contribute to this potentiation.

\section{The effect of $\mathrm{Ca}$ concentration on the procaine-induced potentiation}

The effect of $10^{-5} \mathrm{~g} / \mathrm{ml}$ procaine on twitch tension was studied at various concentrations of $\mathrm{Ca}$ between 1.2 and $7.2 \mathrm{~mm}$. Figure 4a shows an example in which $\mathrm{A}, \mathrm{B}, \mathrm{C}$ and $\mathrm{D}$ illustrate the effect of procaine in solutions which contain 2.4, 1.2, 4.8 and $7.2 \mathrm{~mm} \mathrm{Ca}$, respectively. In Fig. $4 \mathrm{~b}$, peak tensions of various concentrations of $\mathrm{Ca}$ are plotted (filled circles, $n=5$ ) in relation to that of the control $\mathrm{Ca}$ concentration $(2.4 \mathrm{~mm} \mathrm{Ca})$. Next, the procaine-induced twitch tensions at respective $\mathrm{Ca}$ concentrations are plotted in relation to the control twitch tension of $2.4 \mathrm{~mm} \mathrm{Ca}$ (open circles, $n=5$ ). Further, to investigate the Ca dependency of 
the procaine-induced twitch potentiation (triangle marks), each of the values of the filled circles was subtracted from the open circles. When the concentration of $\mathrm{Ca}$ was increased from 1.2 to $2.4 \mathrm{~mm}$, the twitch tension increased because of the increase in the maximum rate of rise of twitch tension. A further increase

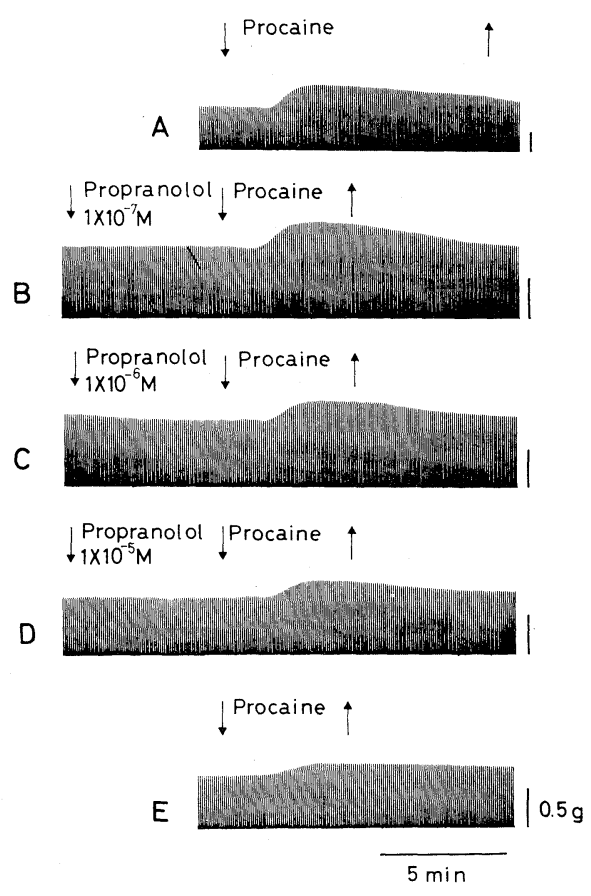

Fig. 3. The effect of propranolol on procaine-induced twitch potentiation. Record A shows a control twitch potentiation induced by procaine $\left(10^{-5} \mathrm{~g} / \mathrm{ml}\right)$. Records $\mathrm{B}, \mathrm{C}$ and $D$ show the effects of propranolol $1 \times 10^{-7}, 1 \times 10^{-6}$ and $1 \times 10^{-5} \mathrm{M}$, respectively. Propranolol was applied between the first downward arrow and the upward arrow for $10 \mathrm{~min}$. At the second downward arrow, procaine $\left(10^{-5} \mathrm{~g} / \mathrm{ml}\right)$ was applied. Record $\mathrm{E}$ shows a final control after propranolol washout.

of the $\mathrm{Ca}$ concentration from 4.8 to $9.6 \mathrm{~mm}$ suppressed the twitch tension by decreasing the time to peak tension, probably due to the shortening of the action potential duration (NIEDERGERKE and ORKAND, 1966). However, the effect of procaine on twitch tension differed from that of $\mathrm{Ca}$ concentration, that is, when the $\mathrm{Ca}$ concentration was increased from 2.4 to $9.6 \mathrm{mM}$, the procaine-induced twitch potentiation increased. Although the procaine-induced twitch potentiation slightly increased when the $\mathrm{Ca}$ concentration was lowered from 2.4 to $1.2 \mathrm{mM}$, this increase seems not to be essential, because this potentiation was not statistically significant. 

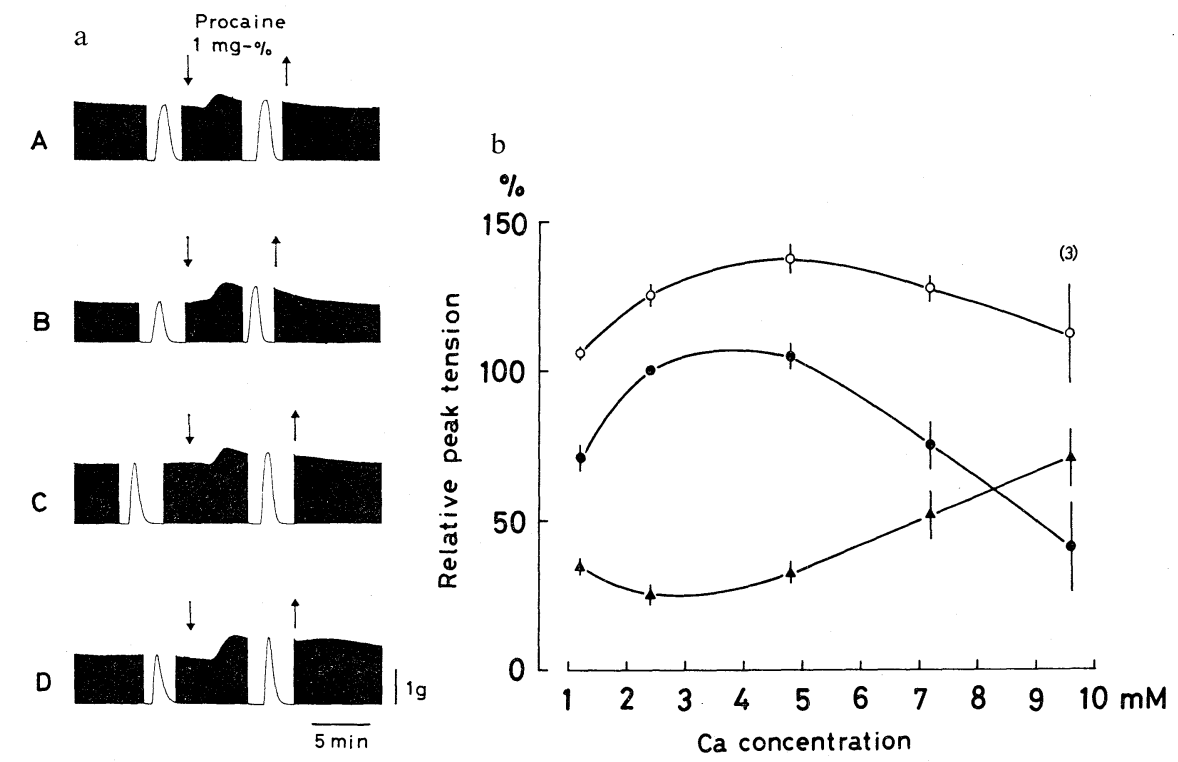

Fig. 4. The effect of procaine at various $\mathrm{Ca}$ concentrations. a: The effect of procaine $\left(10^{-5} \mathrm{~g} / \mathrm{ml}\right)$ at a Ca concentration of $2.4 \mathrm{~mm}$ in $\mathrm{A}, 1.2 \mathrm{~mm}$ in $\mathrm{B}, 4.8 \mathrm{~mm}$ in $\mathrm{C}$ and $7.2 \mathrm{~mm}$ in $\mathrm{D}$. In all records, the last control contraction and the last procaine-treated contraction were recorded at a faster paper speed $(\mathrm{mm} / \mathrm{sec})$ than the rest of the experiment $(\mathrm{mm} / \mathrm{min})$. b: Filled circles show the peak tension $(\%)$ relative to that of control $(2.4 \mathrm{~mm} \mathrm{Ca})$ at various $\mathrm{Ca}$ concentrations $(n=5)$; open circles show the relative procaine $\left(10^{-5} \mathrm{~g} / \mathrm{ml}\right)$ induced twitch potentiation to the control twitch tension of $2.4 \mathrm{~mm} \mathrm{Ca}$ at various $\mathrm{Ca}$ concentrations $(n=5)$; triangle marks show the increase of twitch tension induced by procaine (filled circles subtracted from open circles). The vertical bars represent the standard errors of the means.

\section{The effect of procaine on the potassium contracture}

Figure 5 shows a contracture response produced by an application of $100 \mathrm{~K}$ $14 \mathrm{Na}$ solution for $5 \mathrm{~min}$. It is apparent that the contracture consists of two components, an initial phasic component and a late tonic one. After twitch contraction had sustained a steady level in normal Ringer, $10^{-5} \mathrm{~g} / \mathrm{ml}$ procaine was applied for $10 \mathrm{~min}$ and a contracture solution containing the same concentration of procaine was then perfused for $5 \mathrm{~min}(\mathrm{~B})$. It is clear that both the initial phasic component and the tonic component were markedly suppressed to about $78.2 \pm$ $7.4 \%(n=5)$ of the control potassium contracture. According to the previous dose-response experiment (Fig. 1a), the twitch potentiation by procaine does not disappear during procaine perfusion for $12 \mathrm{~min}$. Therefore the inhibition of potassium contracture is independent of the procaine-induced twitch potentiation. The reason why the recovery of twitch tension after potassium contracture in the procainetreated ventricular muscle (Fig. 5B) was faster than that of control (Fig. $5 \mathrm{~A}, \mathrm{C})$ is not understood, but the rapid recovery of twitch tension in procaine- 


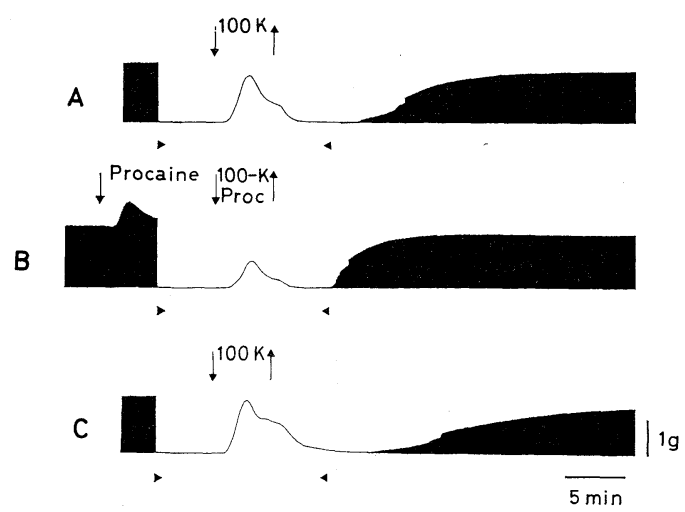

Fig. 5. The effect of procaine on potassium contracture. Record A shows a control contracture induced by a 5 -min perfusion with high $\mathrm{K}$ solution. The stimulation was interrupted for $15 \mathrm{~min}$ between the triangle marks below each record. In record $\mathrm{B}$, procaine $\left(10^{-5}\right.$ $\mathrm{g} / \mathrm{ml}$ ) was applied between the first downward and upward arrows for $15 \mathrm{~min}$. The second downward arrow shows the application of the high $\mathrm{K}$ solution. Record $\mathrm{C}$ shows the recovery.

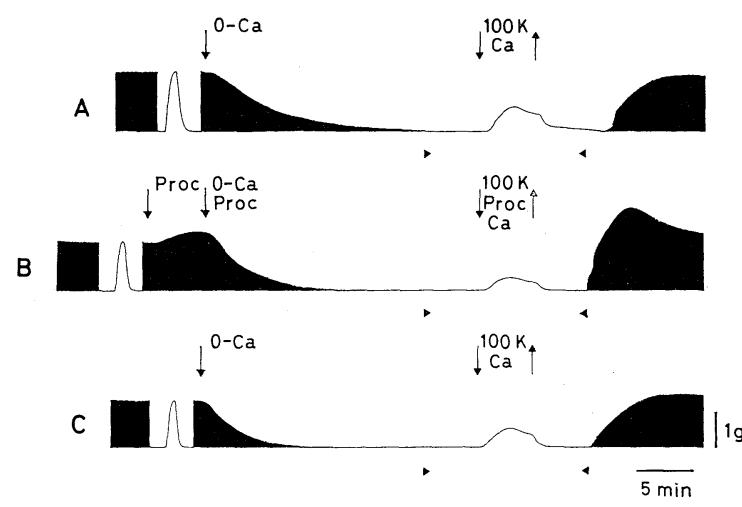

Fig. 6. The effect of procaine on potassium contracture in Ca-free solution. The stimulation was interrupted for $15 \mathrm{~min}$ between triangle marks. Record A shows a control contracture induced by a 5 -min perfusion with Ca-containing high $\mathrm{K}$ solution after perfusion with $\mathrm{Ca}$-free solution for $25 \mathrm{~min}$. At the second downward arrow, Ca-free solution was replaced by $\mathrm{Ca}$-containing high $\mathrm{K}$ solution. The upward arrow shows the beginning of a wash with normal Ringer solution. In $\mathrm{B}$, procaine $\left(10^{-5} \mathrm{~g} / \mathrm{ml}\right)$ was applied between the first downward and upward arrows for $35 \mathrm{~min}$. The final control of potassium contracture in $\mathrm{C}$ is as large as that of the first control.

treated muscle may be due to the small potassium contracture.

The inhibitory action of procaine on potassium contracture after perfusion with Ca-free solution containing $10^{-5} \mathrm{~g} / \mathrm{ml}$ procaine is shown in Fig. 6. Procaine considerably augmented twitch contraction whereas it suppressed the potassium 
contracture (Fig. 6B), and this suppression was $51.3 \pm 6.4 \%(n=5)$ of the maximum contracture obtained in normal Ringer with elevated $(100 \mathrm{~mm}) \mathrm{K}$.

In Fig. 7 following an hour's perfusion in normal Ringer solution, $200 \mu \mathrm{M}$ La was applied between the first downward and upward arrow for $25 \mathrm{~min}$. After the twitch tension disappeared, Ca-free and La-containing solution was perfused

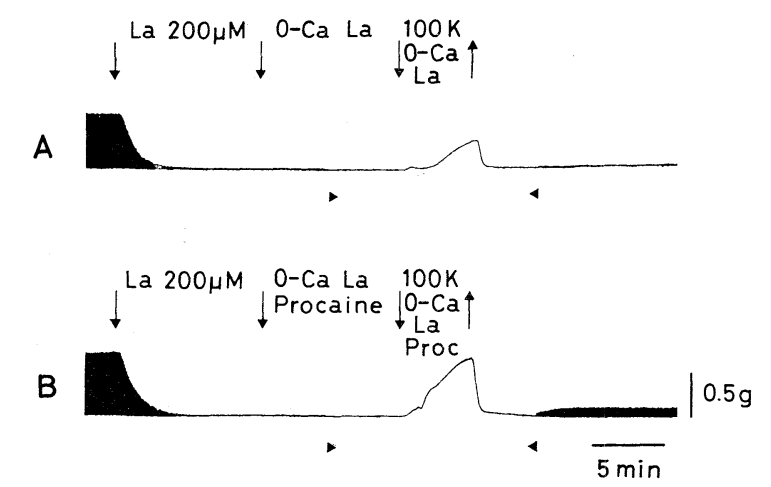

Fig. 7. The effect of procaine on potassium contracture in La-treated Ca-free solution. Record A shows a control record perfused with $100 \mathrm{~K}$ for $5 \mathrm{~min}$. Record $\mathrm{B}$ shows the effect of procaine on the high $\mathrm{K}$ solution.

for $10 \mathrm{~min}$ in order to eliminate the effects of extracellular Ca (SANBORN and LANGER, 1970; RICH and LANGER, 1975). According to their experiment (RICH and LANGER, 1975) the concentration of $100 \mu \mathrm{M}$ La was sufficient to abolish the twitch tension, so the concentration of $200 \mu \mathrm{M}$ La used in this experiment would be enough for this purpose. Then the $100 \mathrm{~K}-14 \mathrm{Na}$-Ca-free-La solution was perfused. The $100 \mathrm{~K}-14 \mathrm{Na}$-Ca-free-La solution brought about potassium contracture which might be induced by intracellular $\mathrm{Ca}$ because extracellular $\mathrm{Ca}$ had been removed from this preparation. Potassium contracture composed only of a tonic component was augmented with procaine (Fig. 7B). When the twitch tension during washout with normal Ringer solution returned to the original level in the latter condition (B), the recovery rate of twitch was $30 \%$ in the former (A).

\section{DISCUSSION}

The results showed that procaine $10^{-5} \mathrm{~g} / \mathrm{ml}$ exerted a positive inotropic effect and a prolongation of action potential in frog ventricular muscle. These effects of procaine are different from the effect proposed for a turtle heart and sheep heart. BAIRD and HARDMAN (1961) showed that procaine reduced the strength of contraction at the concentration of procaine between 1 and $4 \times 10^{-4} \mathrm{M} /$ liter in perfused turtle heart. In sheep heart, THORENs (1971) reported that $4 \times 10^{-4} \mathrm{~g} / \mathrm{ml}$ procaine decreased the duration of the action potential and reduced the strength 
of contraction. In Purkinje fibers, local anesthetics reduced the rate of rise of the action potential explained by an inactivation of the rapid $\mathrm{Na}$ inward current (WeidmanN, 1955).

To explain the present results of the positive inotropic effect of procaine on frog heart, two mechanisms are considered; the first is an increase of a transmembrane $\mathrm{Ca}$ inward current and the second is an increase of intracellular translocation or turnover of $\mathrm{Ca}$. As to the first possibility, the procaine-induced prolongation of the action potential may be caused by an increase of the Ca inward current. In addition, twitch tension in procaine solution was augmented in proportion to the external $\mathrm{Ca}$ concentration between 2.4 and $7.2 \mathrm{mM}$. The potentiation seen at a higher $\mathrm{Ca}$ concentration was accompanied by a corresponding prolongation in the time to peak tension which probably reflects a prolongation of action potential duration, that is, it seems that procaine restored the action potential duration which had been shortened by an increase in Ca concentration (NIEDERGERKE and ORKAND, 1966). These results may be consistent with the previous reports that $\mathrm{Ca}$ ion antagonized the action of procaine in some excitable tissues such as the giant axon of the lobster (BlausteIn and Goldman, 1966) and the phrenic nerve of the rat (SEEman et al., 1974). However, Thorens (1971) reported in sheep heart that a negative inotropic effect of procaine $\left(4 \times 10^{-4} \mathrm{~g} / \mathrm{ml}\right)$ was observed. Although the difference between his results and those of this experiment may be due to the difference in the concentration of procaine, according to a dose-response relation in this experiment, at over $10^{-4} \mathrm{~g} / \mathrm{ml}$ of procaine twitch was suppressed and sometimes there was a block of twitch. Thorens explained this negative inotropism by the shortening of the action potential. Moreover, according to him, in a low $\mathrm{Na}$ solution, procaine reduced the $\mathrm{Ca}$ inward current.

As to the second possibility, namely the participation of intracellular $\mathrm{Ca}$, the suppression of potassium contracture caused by procaine in spite of its positive inotropism would be related to a mobilization of $\mathrm{Ca}$ ions from some intracellular sites (Figs. 5 and 6). It is well known that noradrenaline suppresses potassium contracture in spite of twitch potentiation in both the mammalian and the frog hearts (Kavaler and Morad, 1966; Morad and Rolett, 1972). MORAD and RoLETT (1972) explained this effect by a facilitation of Ca uptake into the intracellular storage site. However, because the relaxation time of the potentiated twitch tension with procaine is not altered, a facilitation of $\mathrm{Ca}$ uptake by procaine seem not to have occurred. However, $10^{-5} \mathrm{~g} / \mathrm{ml}$ procaine potentiated potassium contracture pretreated with $\mathrm{La}$ (Fig. 7B). In this case, intracellular Ca must have contributed mainly to potassium contracture. Although potassium contracture in normal Ringer (Fig. 5) has two components, the initial phasic component and a late tonic one, potassium contracture treated with La (Fig. 7) is composed only of a tonic component. Hence, the tonic component may be caused by intracellu lar $\mathrm{Ca}$. On the contrary, extracellular $\mathrm{Ca}$ mainly contributes to the phasic component 
because of the suppression of the phasic component after Ca-free perfusion (Fig. 6) compared with the contracture of Fig. 5. This observation that potassium contracture is composed of two components was reported in frog (NIEDERGERKE, 1956) and bullfrog ventricle (KAWATA and HATAE, 1977).

It is suggested that procaine acts on the inner surface membrane or intracellular storage site and loosens the binding between $\mathrm{Ca}$ and the storage site. The observations in these experiments seem not to agree with FEINSTEIN's results (1963) in frog skeletal muscle and the result of CHAPMAN and MiLler (1974) in frog heart muscle, that the effect of procaine, $2-4 \mathrm{~mm}\left(5.5-11 \times 10^{-4} \mathrm{~g} / \mathrm{ml}\right)$, acts as a competitive inhibitor of caffeine and inhibits $\mathrm{Ca}$ release from the intracellular binding site. In addition, Ca release from the sarcoplasmic reticulum was inhibited by $2-5 \mathrm{~mm}\left(5.5-13.7 \times 10^{-4} \mathrm{~g} / \mathrm{ml}\right)$ procaine in the rabbit microsomal fractions (CARVAlHo, 1968) and $3.3 \mathrm{~mm}\left(9 \times 10^{-4} \mathrm{~g} / \mathrm{ml}\right)$ procaine in frog microsomal fractions (WEBER and Herz, 1968). However, the present results agree with the reports of ISAACSON et al. (1970) that in rat skeletal muscle $20 \mathrm{~mm} / \mathrm{liter}\left(5.5 \times 10^{-3} \mathrm{~g} / \mathrm{ml}\right)$ procaine increases the force of contraction without suppressing the caffeine contracture, and with the results of BONDANI and KARLER (1970) who reported that procaine $25 \mathrm{~mm} /$ liter $\left(6.8 \times 10^{-3} \mathrm{~g} / \mathrm{ml}\right)$ inhibited $\mathrm{Ca}$ binding by skeletal muscle microsomes. The concentration of procaine used in this experiment was much lower than that of the procaine used by previous investigators.

Thus, both extracellular $\mathrm{Ca}$ and intracellular bound $\mathrm{Ca}$ are important for the twitch potentiation induced by procaine.

In frog ventricle, in spite of the poor development of the sarcoplasmic reticulum (Staly and Benson, 1968; PAge and Niedergerke, 1972) the intracellular storage $\mathrm{Ca}$ seems to be important for the contractile system. Ca-induced release of $\mathrm{Ca}$ has been suggested both in skeletal and heart muscle (ENDO et al., 1970; FoRD and Podolsky, 1970; Winegrad, 1976; Fabiato and Fabiato, 1972).

The mechanism of the suppression of potassium contracture (Figs. 5 and 6) was considered as follows. Storage $\mathrm{Ca}$, which was loosened by $10^{-5} \mathrm{~g} / \mathrm{ml}$ procaine, was released in quantity by high $\mathrm{K}$, and some $\mathrm{Ca}$ ions were used for contraction while others were extruded outside the sarcolemma by means of a K-Ca exchange mechanism (MORAD and ORKand, 1971; Morad and Goldman, 1973). The reason for the suppression of potassium contracture in Ca-free solution (Fig. 6) was probably an increase in $\mathrm{Ca}$ extrusion by means of a $\mathrm{Ca}$ concentration gradient when perfusing with a Ca-free solution.

The author wishes to express her gratitude to Prof. H. Kawata for his guidance and discussion for this paper.

\section{REFERENCES}

Baird, W. M. and HARdman, H. F. (1961) An analysis of the effect of pH, procaine cation, nonionized procaine and procaine ethylchloride cation upon cardiac conduction time, stimulation threshold, amplitude of contraction and the relationship of these parameters 
to antiarrhythmic activity. J. Pharmacol. Exp. Ther., 132: 382-391.

Blaustein, M. P. and Goldman, D. E. (1966) Competitive action of calcium and procaine on lobster axon. J. Gen. Physiol., 49: 1043-1063.

BondANI, A. and KARLer, R. (1970) Interaction of calcium and local anesthetics with skeletal muscle microsomes. J. Cell. Comp. Physiol., 75: 199-212.

Carvalho, A. P. (1968) Calcium-binding properties of sarcoplasmic reticulum as influenced by ATP, caffeine, quinine, and local anesthetics. J. Gen. Physiol., 52: 622-642.

Chapman, R. A. and Miller, D. J. (1974) The effects of caffeine on the contraction of the frog heart. J. Physiol., 242: 589-613.

Endo, M., TanaKa, M., and Ogawa, Y. (1970) Calcium-induced release of calcium from the sarcoplasmic reticulum of skinned skeletal muscle fibres. Nature, 228: 34-36.

FABiAto, A. and Fabiato, F. (1972) Excitation-contraction coupling of isolated cardiac fibers with disrupted or closed sarcolemmas. Circ. Res., 31:293-307.

Feinstein, M. B. (1963) Inhibition of caffein rigor and radiocalcium movements by local anesthetics in frog sartorius muscle. J. Gen. Physiol., 47: 151-172.

Ford, L. E. and PoDOlsky, R. J. (1970) Regenerative calcium release within muscle cells. Science, 167: 58-59.

Gruener, R. (1967) Caffeine contractures in sarcolemma-free muscle fibres. J. Physiol., 191: 106-108.

Hagiwara, S., Hayashi, H., and TAKahashi, K. (1969) Calcium and potassium currents of the membrane of a barnacle muscle fibre in relation to the calcium spike. J. Physiol., 205: 115-129.

Heistracher, P. and Hunt, C. C. (1969) The effect of procaine on snake twitch muscle fibres. J. Physiol., 201 : 627-638.

IsAACSON, S., MARILYN, J. H., and TAYlor, S. R. (1970) Contracture and twitch potentiation of fast and slow muscles of the rat at 20 and $37^{\circ} \mathrm{C}$. Am. J. Physiol., 218: 33-41.

Kavaler, F. and Morad, M. (1966) Paradoxical effects of epinephrine on excitation-contraction coupling in cardiac muscle. Circ. Res., 18: 492-501.

Kawata, H. and Hatae, J. (1977) Contractile behaviour of cardiac ventricular muscle in strontium solution. Jpn. J. Physiol., 27: 167-184.

Kurihara, S. (1975) The effect of procaine on the mechanical and electrical activities of the smooth muscle cells of the guinea pig urinary bladder. Jpn. J. Physiol., 25: 775-788.

KurIHARA, S. and SAKAI, T. (1976) Inhibitory effects of procaine on the electrical and mechanical activities of the smooth muscle cells of the guinea pig urinary bladder. Jpn. J. Physiol., 26: 503-516.

Morad, M. and ORKAND, R. K. (1971) Excitation-contraction coupling in frog ventricle: Evidence from voltage clamp studies. J. Physiol., 219: 167-189.

Morad, M. and RoletT, E. (1972) Relaxing effect of catecholamines on mammalian heart. J. Physiol., 224: 537-558.

Morad, M. and Goldman, Y. (1973) Excitation-contraction coupling in heart muscle: Membrane control of development of tension. Prog. Biophys. Mol. Biol., 27: 257-313.

Narahashi, T., Anderson, N. C., and Moore, J. W. (1967) Comparison of tetrodotoxin and procaine in internally perfused squid giant axons. J. Gen. Physiol., 50: 1413-1428.

Niedergerke, R. (1956) The potassium chloride contracture of the heart and its modification by calcium. J. Physiol., 134: 584-599.

Niedergerke, R. and ORKAND, K. (1966) The dual effect of calcium on the action potential of the frog's heart. J. Physiol., 184: 291-311.

Page, S. G. and Niedergerke, R. (1972) Structure of physiological interest in the frog heart ventricle. J. Cell Sci., 11: 179-203.

Sanborn, W. G. and Langer, G. A. (1970) Specific uncoupling of excitation and contraction

Vol. 29, No. 1, 1979 
in mammalian cardiac tissue by lanthanum. J. Gen. Physiol., 56: 191-217.

Rich, T. L. and LANGER, G. A. (1975) A comparison of excitation-contraction coupling in heart and skeletal muscle: an examination of "calcium-induced calcium release." J. Mol. Cell. Cardiol., 7: 747-765.

Seeman, P., Chen, S. S., Chau-wong, M., and Staiman, A. (1974) Calcium reversal of nerve blockade by alcohols, anesthetics, tranquilizers, and barbiturate. Can. J. Physiol. Pharmacol., 52: 526-534.

Staley, N. A. and Benson, E. S. (1968) The ultrastructure of frog ventricular cardiac muscle and its relationship to the mechanism of excitation-contraction coupling. J. Cell Biol., 38: $99-114$.

THORENS, S. (1971) Electrical and mechanical effects of procaine on mammalian heart muscle. Pflügers Arch., 324: 56-66.

Weber, A. and Herz, R. (1968) The relationship between caffeine contracture of intact muscle and the effect of caffeine on reticulum. J. Gen. Physiol., 52: 750-759.

WeidmanN, S. (1955) Effects of calcium ions and local anesthetics on electrical properties of Purkinje fibres. J. Physiol., 129: 568-582.

Winegrad, S. (1976) Spontaneous mechanical activity in depolarized frog ventricle. J. Gen. Physiol., 68: 145-157. 